舌下腺腺様囊胞癌例

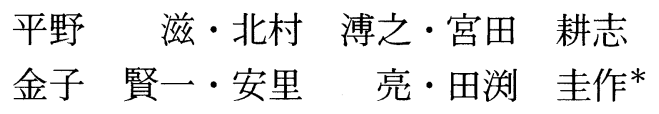

\title{
Adenoid Cystic Carcinoma of Sublingual Gland ; A Case Report
}

\author{
Shigeru Hirano, Hiroyuki Kitamura, Koji Miyata, \\ Ken-ichi Kaneko and Ryo Asato
}

(Tenri Hospital)

\author{
Keisaku Tabuchi \\ (Takatsuki Red Cross Hospital)
}

Malignant tumors of the sublingual gland are uncommon. We report here a case of adenoid cystic carcinoma of the sublingual gland.

A 36-year-old woman was refered to our hospital with a swelling of the floor of the mouth on the left side. MRI showed a tumor of the left sublingual gland. Fine needle aspiration biopsy (FNA) revealed adenoid cystic carcinoma. Resection of the left oral floor and left submandibular neck dissection were performed, and $50 \mathrm{~Gy}$ post operative irradiation was given.

MRI and FNA were very useful in the diagnosis of the sublingual tumor.

Key words: adenoid cystic carcinoma, sublingual gland, FNA

はじめに

大唾液腺腫瘍の殆どは耳下腺, 顎下腺に発生 し, 舌下腺に発生する割合は $0.2 \sim 4.7 \%{ }^{11}$ と 極めて稀で，その $80 \%$ 以上が悪性とされてい $3^{2) 3)}$. 今回, 舌下腺原発の腺様囊胞癌の一例 を経験し，その診断と治療法につき若干の知見 を得たので報告する。

\section{症例}

患者 : 36歳, 女性.

主訴：口腔底腫脹.

既往歴：特記すべきことなし.
家族歴 : 特記すべきことなし.

現病歴: 初診の約 1 年前より, 口腔底の腫脹 を自覚していたが放置し，徐々に腫脹の増大と 疼痛を覚え, 平成 4 年 3 月 10 日当科を受診した。 初診時所見：左口腔底に最大径 $32 \mathrm{~mm}$ の表 面不整で硬い腫瘍を認めた（図 1 )。表面の粘膜 は正常で, 周囲との癒着はなく, 可動性も良好 であったが，圧痛を認めた。頸部にリンパ節腫 脤を触知しなかった。

検査所見：MRI 上, 左舌下腺に $\mathrm{T} 1$ 強調像 で高信号を呈し，ガドリニウムによって著明に 
増強される腫瘍を認めた。周囲への浸潤はなか った(図 2 ). 穿刺吸引細胞診 (fine needle aspiration biopsy; FNA) で核の増生と cribriform pattern の細胞配列を認め, Papanicolauの分 類で class $\mathrm{V}$, 腺様哇胞癌と診断された(図 3 ).

全身所見：一般血液生化学検査，尿検査に異 常なく，心電図，胸部X線も正常であった.

入院後経過 : 以上の局所所見，検査結果上り， 舌下腺原発の腺様賈胞癌 T2aN0M0 と診断し, 全身麻酔下に手術を施行した．先ず口腔底切開 により腫瘍を摘出した。腫瘍は周囲との瘉着な く容易に摘出できた。術中迅速病理で “腺様襄

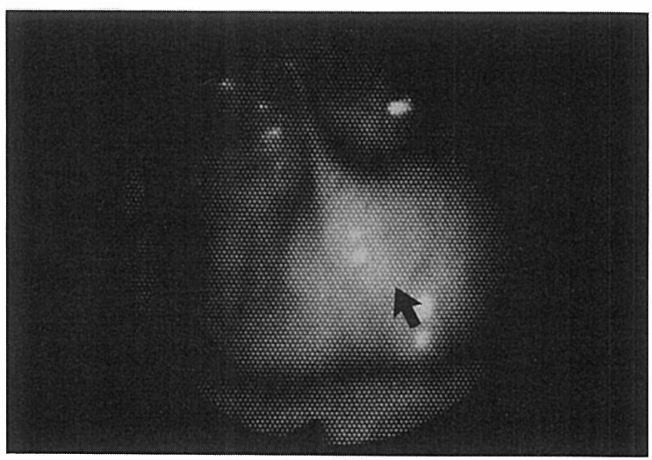

図 1 初診時口腔底所見 口腔底左側の腫脹を認める(令). 粘膜は正常である。
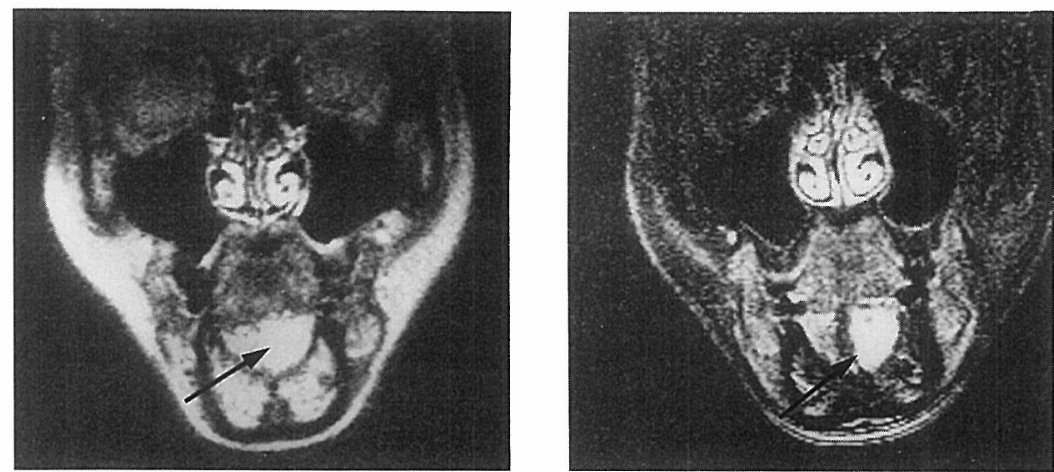

図 2 MRI 所見

左 : T1 強調像で左舌下腺に高信号を呈する腫癔を認める $(\rightarrow)$. 右：ガドリニウムで著明に増強されている $(\rightarrow)$.
胞癌”の確定診断を得た後, 舌神経, ワルトン 管を含めた口腔底の郭清と, 左顎下部の郭清を 行った.

摘出標本：割面が白色均一な舌下腺の殆どを 占める充実性腫瘍であった(図 4 ).

術後14日目より原発巣にリニアック50 Gy を照射し，平成 4 年 6 月 21 日退院した。

病理組織所見：典型的な cribriform pattern の腺様襄胞癌であった（図 5 ).

退院後経過：退院後 1 年であるが, 再発, 転 移徴候を認めていない。

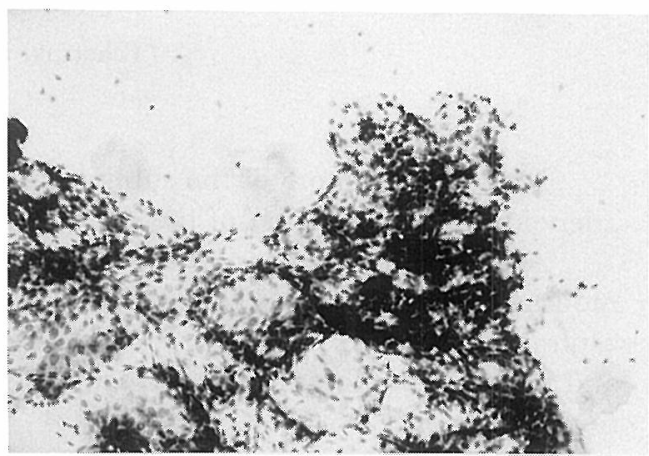

図 3 細胞診所見

核の異型は少ないが，核の増生と cribriform patternの配列を示し, 典型的な腺様㐮胞癌の細胞 像を呈している。 
考察

舌下腺悪性腫瘍の報告は1930年 Brunschwig に始まり, Uchiyama らが1988年までの73例を 集計している1)が，今回我々が渉猟し得た限り では，自験例を含め内外めわせて 82例144) 7) で， 稀な疾患といえる。病理組織像は腺様雯胞癌が 最も多く33例で，以下粘表皮腫，多形腺腫内癌 の順となっていた(表 1 ).

舌下腺腫瘍の場合，その大部分が悪性とされ て特り，腫瘍の性状に関寸る正確な診断と適切 な治療が必要となる。術前診断には, 顎下腺造 影，CT， MRI，シンチグラム，更に生検があ るが，今回の症例での経験から，MRI と FNA とが特に有用と考光られた。すなわち，口腔底

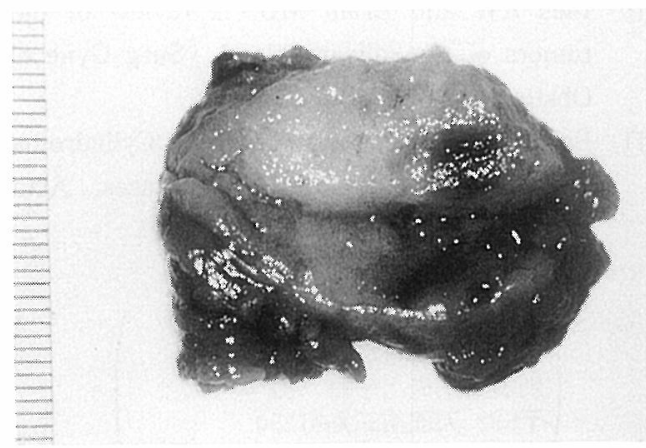

図 4 摘出標本 割面が白色均一の充実性腫瘍であった。

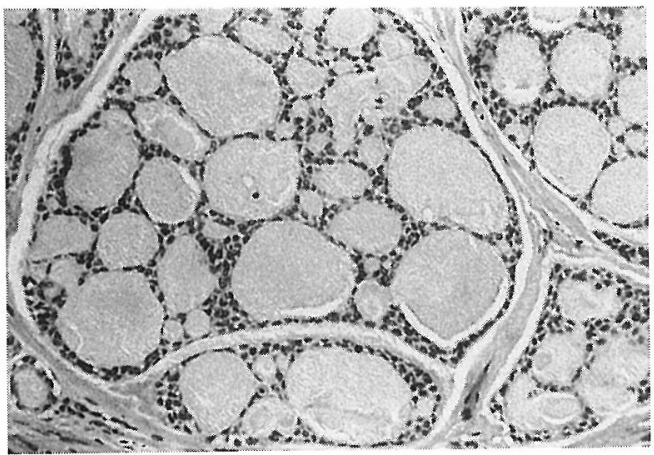

図 5 病理組織像 $($ H.E. 染色 $\times 100)$ 典型的な cribriform pattern の配列を認め, 腺様雚胞癌と診断された。
の部位診断に，CT ではアーチファクトを受け やすく周囲組織との位置関係が不明瞭であり, MRIの方がより明瞭に腫瘍の描出が可能であ ることがわかった，術前の生検に関しては賛否 両論があり，これに関する報告114) もみられる が，生検では侵襲も少なくなく，播種の危険性 も影念され，Rankow ら2) 女否定的な見解を述 べている. 一方, FNA の利点は, 生検に比べ 侵襲が少なく，播種の危険性が極めて小さいこ と，それでいて高い正諩率を得られることにあ る。今回の文献的検索では FNA 施行の報告は 見いだせなかったが，近年，耳下腺，顎下腺腫 瘍に対するFNA の有効性，安全性の報告は多 く8)9), 本例でも FNA で組織型まで正しく診断 できて扣り，今後舌下腺腫瘍に対しても FNA を利用すべきと思われた。

治療法は手術中心となっているが，腺様靯胞 癌では，神経浸潤を来しやすいことを考慮する と，舌神経を含め周囲組織を充分付けた腫瘍の 完全摘出が必要と考兄られる。放射線療法に関 しては，感受性は低いとされながらもその有効 性を指摘する報告は多く10)11), Berdal ら ${ }^{11)}$ は, radiocurable ではないが radiosensitive である と述べている．腺様裂胞癌が緩徐な発育を示し 10年以上経過してからも局所再発や遠隔転移を 来すことがある点を考慮すると，手術十術後照 射が妥当な治療法と考它られた。

舌下腺癌の予後は，これに関する文献が少な く推定が困難であるが，腺様琵胞癌に関しては，

表 1 舌下腺悪性腫瘍の組織像

\begin{tabular}{ll}
\hline \hline 腺様銮胞癌 & 33 例 \\
粘表皮腫 & 18 \\
多形腺腫内癌 & 11 \\
腺 癌 & 9 \\
腺房細胞腫 & 5 \\
類表皮癌 & 1 \\
未分化癌 & 1 \\
その他 & 4 \\
\hline 計 & 82
\end{tabular}


死亡例 1 例2)，9 カ月から13年の観察期間で生 存例 5 例と報告されて扮り，本例のように完全 摘出がでされば予後は良好と考兄られるが，な 打長期的な観察が必要であろう。

\section{まとめ}

1. 舌下腺原発の腺様囊胞癌の一例を経験し た.

2. 診断に MRI と FNA が有効であった。

3. 治療は手術による腫瘍の完全摘出と術後 放射線療法が最も良い方法と考兄られた。

稿を終えるに当たり, 御校閲, 御指導を賜りまし た京都大学医学部耳鼻咽喉科学教室本庄 嚴教授に 深謝致します。

本論文の要旨は, 第242回日耳鼻大阪地方部会に㧤 いてロ演した.

\section{参考文献}

1) Uchiyama $K$, Ikeuchi $S$, Shiba $H$, et al : Adenocarcinoma of the sublingual gland. Keio J Med $40: 20 \sim 24,1991$.

2) Rankow RM and Mignogna $F$ : Cancer of the sublingual salivary gland. Am J Surg 118 : 790 795, 1969.

3) Turnbull $\mathrm{AD}$ and Frazell EL : Multiple tumors of the major salivary glands. Am J Surg 118 : 787 789, 1969.

4）渡辺昭仁，野平久化彦，畔田 貢，他：舌下腺 にみられた腺癌例。耳鼻臨床 $84: 193 \sim 196$,
1991.

5）篠原正徳, 嶋田 誠, 堀之内康文, 他 : 唾液腺 悪性腫瘍の臨床的・病理組織学的検索 一舌下 腺, 小唾液腺原発症例について一. 日本喠液腺 学会誌 31：87〜90, 1990.

6）松下文彦，水野明夫，中村真一，他：口底に発 生した粘表皮腫の 2 例.口科誌 $38: 609 \sim 614$, 1989.

7) Hamper K, Brugmann M, Caselitz J, et al : Prognosis of salivary adenocarcinomas. Virchows Archiv A Pathol Anat $416:$ 57 64, 1989.

8) Smith MA and Frable WJ : Fine needle aspiration biopsy of salivary glands. Laryngoscope $101: 245 \sim 249,1991$.

9）野々村光栄, 福島英行, 児嶋久剛, 他 : 耳下腺 腫瘍に拈ける術前診断の検討. 耳鼻臨床 83 : 1409 1413, 1990.

10) Illes RW and Brian MB : A review of the tumors of the salivary gland. Surg Gynecol Obstet 163 : 399 404, 1986.

11) Berdal $P$, Beshe A and Mylius E : Cylindroma of salivary glands ; a report of 80 cases. Acta Otolaryngol $263: 170 \sim 173,1970$.

$\left(\begin{array}{l}\text { 原稿受付 : 平成 } 4 \text { 年 } 10 \text { 月 } 8 \text { 日 } \\ \text { 原稿採択 : 平成 } 5 \text { 年 } 12 \text { 月 } 2 \text { 日 } \\ \text { 別刷請求先 : 平野 滋 } \\ \text { †6 } 632 \text { 天理市三島町 } 200 \\ \text { 天理よろつ相談所病院耳鼻咽喉科 }\end{array}\right)$

